\title{
PERLINDUNGAN HUKUM BAGI PASIEN KEGAWATDARURATAN BPJS DENGAN DIAGNOSA DI LUAR DAFTAR DIAGNOSA GAWAT DARURAT DI RSUD KABUPATEN SUKOHARJO
}

\author{
Triana Widati \\ e-mail: triana.widati@yahoo.com \\ Pegawai Rumah Sakit Umum Daerah Sukoharjo \\ Hudi Asrori \\ email: hudisayuti@gmail.com \\ Pujiyono \\ email: pujifhuns@stafff.uns.ac.id \\ Dosen Fakultas Hukum UNS
}

\begin{abstract}
This article examines the legal protection of BPJS emergency patients with diagnoses beyond the emergency diagnostic list and factors that may inhibit the emergency services for BPJS user patients at the Sukoharjo District Hospital. This type of research is empirical. Form of research is deskriptif. The dara used are primary data, secondary data and tertiery data collection methode of documentation and interviews. Analysis of data using qualitative analysis. Based on the description of the results of research and discussion in connection with the considered promblems with the teory of the working of the legal system and the legal protection teory, it can be concluded that the legal protection of BPJS participants and the right to submit a complaint related to the health service in the National Health Insurance (JKN). Based on Article 25 letter $b$ of Presidential Regulation Number 12 of 2013, services that are not guaranteed are services performed in health facilities that are not cooperated with BPJS Health, except in emergency conditions, but the emergency condition condition has also been determined, if the people who have emergency discharge. Factors that can inhibit the emergency services for patients using BPJS in RSUD Sukoharjo District, among others, the legal factor which limits the emergency conditions.
\end{abstract}

Key Word: Legal Protection; Patients; Emergency Diagnosis

\begin{abstract}
Abstrak
Artikel ini bertujuan untuk mengkaji perlindungan hukum bagi pasien kegawatdaruratan BPJS dengan diagnosa di luar daftar diagnosa gawat darurat dan faktor-faktor yang dapat menghambat dalam pelayanan kegawatdaruratan bagi pasien pengguna BPJS di RSUD Kabupaten Sukoharjo. Jenis penelitian ini adalah empiris. Bentuk penelitian deskriptif analitis. Data yang digunakan adalah data primer, sekunder dan tersier dengan pengumpulan data dokumentasi dan wawancara. Analisis data menggunakan analisis kualitatif. Berdasarkan deskripsi hasil penelitian dan pembahasan sehubungan dengan masalah yang dikaji dengan teori bekerjanya hukum dan teori perlindungan hukum dapat disimpulkan bahwa perlindungan hukum peserta BPJS didasari oleh perlindungan hak memperoleh pelayanan kesehatan sebagai peserta BPJS
\end{abstract}


dan hak menyampaikan keluhan terkait dengan pelayanan kesehatan dalam Jaminan Kesehatan Nasional (JKN). Berdasarkan Pasal 25 huruf b Perpres Nomor 12 tahun 2013 pelayanan yang tidak dijamin adalah pelayanan yang dilakukan di fasilitas kesehatan yang tidak bekerjasama dengan BPJS Kesehatan, kecuali dalam kondisi gawat darurat, namun demikian kondisi kegawat daruratannya juga telah ditentukan, apabila orang-orang yang mengalami kegawatdaruratan yang tidak tertulis maka tidak ditanggung oleh BPJS. Faktor-faktor yang dapat menghambat dalam pelayanan kegawatdaruratan bagi pasien pengguna BPJS di RSUD Kabupaten Sukoharjo antara lain faktor hukum yang membatasi kondisi kegawatdaruratan.

Kata kunci: Perlindungan Hukum; Pasien; Kegawatdaruratan.

\section{A. Pendahuluan}

Kondisidaruratadalahkondisi yang apabila tidak segera diberi pertolongan, bisa mengakibatkan kecacatan, keparahan bahkan kematian. Setelah kondisi kedaruratan terlewati, peserta harus pindah kefasilitas kesehatan yang bekerjasama dengan BPJS, apabila ingin menggunakan haknya sebagai peserta. Apabila kondisi pasien tidak termasuk dalam kriteria gawat darurat? Dalam kondisi TIDAK gawat darurat, biaya pelayanan tidak ditanggung BPJS. Jadi pasien peserta BPJS membayar sendiri dan tidak bisa diklaimkan ke BPJS. Seperti kasus pada pasien yang datang ke Instalasi Gawat Darurat (IGD) RS Puri Asih Salatiga pada tanggal 14 Maret 2015 karena ada keluhan sesak nafas dan dalam kondisi hamil 20 minggu harus membayar biaya pelayanan IGD.

Hal ini menimbulkan permasalahan teknis yaitu, apakah pasien tersebut harus diterima, ataukahpasien tersebut harus di berikan diagnosa lain yang mengikuti dengan kriteriagawatdarurat yang dijamin BPJS. Apabila diagnosanya diganti, maka keakuratan diagnosa dokter akan dipertanyakan, sehingga potensi malpraktek dokter akan terbuka lebar, dan tentunya hal ini juga akan melanggar kode etik dokter.

BPJS dapat disebut sebagai asuransi sosial, karena BPJS Kesehatan merupakan program asuransi yang dikelola pemerintah. Asuransi sosial yang juga biasa disebut asuransi wajib merupakan bentuk asuransi pada umumnya dengan tujuan untuk memberikan jaminan sosial bagi masyarakat atau sebagian anggota masyarakat tertentu. Asuransi sosial timbul karena kebutuhan masyarakat akan terselenggaranya atau terpenuhinya suatu jaminan sosial (social security). Jaminan sosial tersebut dibutuhkan karena keadaan atau bahaya yang terjadi di luar kemampuan dan kehendak dari masyarakat (Suryono,2003:134).

Asuransi dalam terminologi hukum merupakan suatu perjanjian, oleh karena itu perjanjian itu sendiri perlu dikaji sebagai acuan menuju pada pengertian asuransi.Di samping itu karena acuan pokok perjanjian asuransi tetap pada pengertian dasar dari perjanjian. Secara umum pengertian perjanjian dapat dijabarkan antara lain adalah sebagai berikut:

Suatu perbuatan dengan mana satu orang atau lebih mengikatkan dirinya terhadap satu orang atau lebih. Suatu hubungan hukum antara pihak, atas dasar mana pihak yang satu (yang berpiutang atau kreditur) berhak untuk suatu prestasi dari yang lain. (yang berhubungan atau debitur) yang juga berkewajiban melaksanakan dan bertanggung jawab atas suatu prestasi (Hartono, 2001: 82).

Peserta BPJS memiliki hak untuk menikmati pelayanan kesehatan berupa manfaat jaminan sosial kesehatan di RSUD, sedangkan RSUD wajib melayaninya. Pasien 
BPJS adalah konsumen pemakai jasa layanan kesehatan. Sebagai pemakai jasa layanan kesehatan, pasien juga disebut sebagai konsumen sehingga dalam hal ini berlaku juga ketentuan Undang-Undang No. 8 Tahun 1999 tentang Perlindungan Konsumen UUPK. Dengan tidak dilayaninya pasien atas dasar tidak ditanggungnya suatu penyakit, padahal kepesertaan BPJS wajib merupakan pelanggaran Pasal 4 huruf b UU No. 8 Tahun 1999 tentang Perlindungan Konsumen (UUPK), yaitu hak untuk memilih barang dan/ atau jasa serta mendapatkan barang dan/atau jasa tersebut sesuai dengan nilai tukar dan kondisi serta jaminan yang dijanjikan.

RSUD Kabupaten Sukoharjo merupakan satu-satunya rumah sakit milik Pemerintah Daerah yang menjadi rujukan bagi 12 puskesmas di Kabupaten Sukoharjo dan sekitarnya. RSUD Kabupaten Sukoharjo memiliki letak geografis dekat dengan kompetitor rumah sakit besar di Kota Solo. Sejak tanggal 1 Januari 2014 RSUD Kabupaten Sukoharjo telah melayani peserta BPJS, namun sejak melayani pasien BPJS RSUD Kabupaten Sukoharjo selalu menemui kendalah khususnya terhadap pasien kegawat daruratan BPJS yang diagnosa penyakitnya tidak ada dalam daftar diagnosa gawat darurat.

Seorang pasien BPJS tentunya tidak pernah menginginkan sakit, atau memilih dengan penyakit apa ia sakit, sedangkan BPJS merupakan kepesertaan wajib dalam sistem Jaminan Nasional. Apabila seorang pasien ternyata mengalami sakit yang tidak ditanggung oleh BPJS, lalu untuk apa ia mengikuti BPJS karena ia harus membayar sendiri atas biaya pelayanan kesehatan tersebut.

Keadilan adalah hal yang mendasar bagi bekerjanya suatu sistem hukum. Sistem hukum tersebut sesungguhnya merupakan suatu struktur atau kelengkapan untuk mencapai konsep keadilan yang telah disepakati bersama (Rahardjo,2006 : 270).Setiap peraturan hukum menunjukkan aturan-aturan tentang bagaimana seseorang pemegang peran diharapkan untuk bertindak. Tindakan apa yang akan diambil oleh seseorang pemegang peran sebagai respons terhadap peraturan hukum, sangat tergantung dan dikendalikan oleh peraturan hukum yang berlaku, dari sanksi-sanksinya, dari aktivitas lembaga pelaksanaannya, serta dari seluruh kompleks kekuatan sosial, politik, dan lain sebagainya yang bekerja atas dirinya (Warassih, 2011: 21).

Berdasarkan uraian di atas, dalam artikel ini dibahas mengenai perlindungan hukum bagi pasien kegawatdaruratan BPJS dengan diagnosa di luar daftar diagnosa gawat darurat dan faktor-faktor yang menghambat pelayanan kegawatdaruratan bagi pasien BPJS di RSUD Kabupaten Sukoharjo.

\section{B. Metode Penelitian}

Penelitian mengenai Perlindungan Hukum Bagi Pasien Kegawatdaruratan BPJS Dengan Diagnosa Di Luar Daftar Diagnosa Gawat Darurat Di RSUD Kabupaten Sukoharjo ini merupakan penelitian empiris. Penelitian empiris yaitu suatu penelitian yang bertujuan untuk dapat melihat hukum dalam artian nyata serrta meneliti bagaimana bekerjanya hukum di lingkungan masyarakat. Sumber data dalam penelitian ini adalah data primer, data sekunder dan data tersier dengan teknik pengumpulan data dokumentasi dan wawancara.Penyajian data dalam penelitian ini akan menggunakan bentuk teks naratif, yaitu menyajikan data yang sudah diolah dalam uraian teks narasiSoekanto dan Mamudji, 2007: 13) dan analisis data dalam penelitian ini menggunakan metode kualitatif yaitu suatu tata cara penelitian yang menghasilkan data deskriptid-analisis, yaitu apa yang dinyatakan oleh responden secara tertulis atau lisan, dan 
juga perilakunya yang nyata, yang diteliti, dan dipelajari sebagai sesuatu yang utuh (Soekanto, 2010: 250).

\section{Hasil Penelitian dan Pembahasan}

Perlindungan hukum adalah penyempitan arti dari perlindungan, dalam hal ini hanya perlindungan oleh hukum saja. Perlindungan yang diberikan oleh hukum terkait pula dengan adanya hak dan kewajiban, dalam hal ini yang dimiliki oleh manusia sebagai subyek hukum dalam interaksinya dengan sesama manusia serta lingkungannya. Sebagai subyek hukum manusia memiliki hak dan kewajiban untuk melakukan suatu tindakan hukum (Kansil: 1989: 102).

Menurut Setiono, perlindungan hukum adalah tindakan atau upaya untuk melindungi masyarakat dari perbuatan sewenang-wenang oleh penguasa yang tidak sesuai dengan aturan hukum, untuk mewujudkan ketertiban dan ketentraman sehingga memungkinkan manusia untuk menikmati martabatnya sebagai manusia (Setiono, 2004: 3).

Perlindungan hukum pada dasarnya merupakan perlindungan hak seorang warga negara, yang dilindungi oleh hukum.Philipus Hadjon mengartikan perlindungan hukum sebagai perlindungan harkat, martabat dan pengakuan terhadap hak asasi manusia yang dimiliki oleh subyek hukum dalam negara hukum dengan berdasarkan pada ketentuan hukum yang berlaku di negara tersebut guna mencegah terjadinya kesewenang-wenangan. Dengan demikian perlindungan hukum dibagi menjadi dua yaitu perlindungan hukum yang preventif yang bertujuan untuk mencegah terjadinya permasalahan atau sengketa dan perlindungan hukum yang represif yang bertujuan untuk menyelesaikan permasalahan atau sengketa yang timbul (Hadjon, 1987: 117).
Pada perlindungan hukum represif, menurut UU SJSN dan BPJS dan peraturan pelaksananya, Peraturan Menteri Kesehatan Republik Indonesia Nomor 28 Tahun 2014 Tentang Pedoman Pelaksanaan Program Jaminan Kesehatan Nasional, perlindungan hukum dilaksanakan melalui mekanisme keluhan. Apabila penanganan keluhan atas permasalahan yang dihadapi oleh para pihak baik antara Peserta dengan Fasilitas Kesehatan, Peserta dengan BPJS Kesehatan. Penanganan keluhan merupakan salah satu instrumen untuk menyelesaikan masalah pelayanan kesehatan, baik yang bersifat administratif maupun bersifat medis. Permasalahan bisa terjadi antara Peserta dengan Fasilitas Kesehatan; antara Peserta dengan BPJS Kesehatan; antara BPJS Kesehatan dengan Fasilitas Kesehatan; atau antara BPJS Kesehatan dengan Asosiasi Fasilitas Kesehatan.

Berdasarkan Pasal 4 s/d Pasal 8Undang - Undang Nomor 36 Tahun 2009 tentang Kesehatan, hak-hak pasien antara lain:

a. Hak atas Informasi

b. Hak atas Persetujuan

c. Hak atas Rahasia Kedokteran

d. Hak atas Pendapat Kedua (second opinion)

e. Hak untuk Melihat Rekam Medik

Undang-Undang No. 29 Tahun 2004 tentang Praktek Kedokteran juga merupakan Undang-Undang yang bertujuan untuk memberikan perlindungan bagi pasien BPJS. Hak-hak pasien diatur dalam Pasal 52 UU No. 29/2004 adalah:

1) Mendapatkan penjelasan secara lengkap tentang tindakan medis sebagaimana dimaksud dalam pasal 45 ayat (3);

2) Meminta pendapat dokter atau dokter lain;

3) Mendapatkan pelayanan sesuai dengan kebutuhan medis;

4) Menolak tindakan medis;

5) Mendapatkan isi rekam medis. 
Perlindungan hak pasien BPJS juga tercantum dalam Pasal 32 Undang-Undang No. 44 Tahun 2009 tentang Rumah Sakit, yaitu:

1) memperoleh informasi mengenai tata tertib dan peraturan yang berlaku di Rumah Sakit;

2) memperoleh informasi tentang hak dan kewajiban pasien;

3) memperoleh layanan yang manusiawi, adil, jujur, dan tanpa diskriminasi;

4) memperoleh layanan kesehatan yang bermutu sesuai dengan standar profesi dan standar prosedur operasional;

5) memperoleh layanan yang efektif dan efisien sehingga pasien terhindar dari kerugian fisik dan materi;

6) mengajukan pengaduan atas kualitas pelayanan yang didapatkan, dan lainnya;

Dalam konteks perlindungan hukum represif, penyelesaian sengketa antara Peserta BPJS dengan Rumah sakit dapat dilakukan melalui media litigasi/ jalur hukum peradilan. Pasal 58 ayat 1 Undang-Undang UndangUndang Nomor 36 Tahun 2009 menyatakan bahwa, setiap orang berhak menuntut ganti rugi terhadap seseorang, tenaga kesehatan dan/atau penyelenggaraan kesehatan yang menimbulkan kerugian akibat kesalahan atau kelalaian dalam pelayanan kesehatan yang diterimanya, namun demikian dalam Pasal 29Undang Nomor 36 Tahun 2009, menyatakan bahwa, dalam hal tenaga kesehatan diduga melakukan kelalaiandalam menjalankan profesinya, kelalaian tersebut harusdiselesaikan terlebih dahulu melalui mediasi.

Dalam hal pertanggungjawaban atas pelayanan medis yang mana pihak pasien BPJS merasa dirugikan maka perlu untuk diketahui siapa yang terkait di dalam tenaga medis tersebut. Tenaga medis yang dimaksud adalah dokter yang bekerjasamadengan tenaga professional lain di dalam menyelenggarakan dan memberikanpelayanan medis kepada pasien. Dalam kaitannya dengan tanggung jawab rumah sakit selaku badan hukum, maka pada prinsipnya rumah sakit bertanggung jawab secara perdataterhadap semua kegiatan yang dilakukan oleh tenaga kesehatan sesuai dengan bunyi Pasal 1365 KUH Perdata yaitu :

"Tiap perbuatan melawan hukum yang membawa kerugian kepada seorang lain, mewajibkan orang yang karena salahnya menerbitkan kerugian tersebut".

Selain itu juga tertuang dalam Pasal 58 ayat 1 Undang-Undang Undang-Undang Nomor 36 Tahun 2009 yaitu:

"Setiap orang berhak menuntut ganti rugi terhadap seseorang, tenaga kesehatan dan/ atau penyelenggaraan kesehatan yang menimbulkan kerugian akibat kesalahan atau kelalaian dalam pelayanan kesehatan yang diterimanya."

Dalam konteks darurat, penulis memiliki hipotesis bahwa, BPJS tidak dapat mengcover setiap kondisi kegawatdaruratan medis, sehingga merugikan peserta BPJS karena adanya kekosongan hukum. Gawat darurat adalah suatu kondisi klinik yang memerlukan pelayanan medis. Gawat Darurat medis adalah suatu kondisi dalam pandangan penderita, keluarga, atau siapapun yang bertanggung jawab dalam membawa penderita ke rumah sakit memerlukan pelayanan medis segera. Penderita gawat darurat memerlukan pelayanan yang cepat, tepat, bermutu dan terjangkau.

Penderita gawat darurat adalah penderita yang oleh karena suatu penyebab (penyakit, trauma, kecelakaan, tindakan anestesi) yang bila tidak segera ditolong akan mengalami cacat, kehilangan organ tubuh atau meninggal. Berdasarkan Pasal 2 Kode Etik Kedokteran Indonesia (KODEKI), setiap dokter harus senantiasa berupaya melaksanakan profesinya sesuai dengan standar profesi yang tertinggi, 
yaitu sesuai dengan perkembangan IPTEK kedokteran, etika umum, etika kedokteran, hukum dan agama, sesuai tingkat/jenjang pelayanan kesehatan dan situasi setempat. (MKEK, 2002).

Seorang dokter dilarang tidak melakukan pertolongan darurat atas dasar perikemanusiaan, padahal tidak membahayakan dirinya, kecuali bila ia yakin ada orang lain yang bertugas dan mampu melakukannya. Menolong orang lain yang membutuhkan pertolongan adalah kewajiban yang mendasar bagi setiap manusia, utamanya bagi profesi dokter atau dokter gigi di sarana pelayanan kesehatan. Kewajiban tersebut dapat diabaikan apabila membahayakan dirinya atau apabila telah ada individu lain yang mau dan mampu melakukannya atau karena ada ketentuan lain yang telah diatur oleh sarana pelayanan kesehatan tertentu. Undang-Undang Nomor 29 Tahun 2004 tentang Praktik Kedokteran Pasal 51 huruf d menyatakan Dokter atau dokter gigi dalam melaksanakan praktik kedokteran mempunyai kewajiban melakukan pertolongan darurat atas dasar perikemanusiaan, kecuali bila ia yakin ada orang lain yang bertugas dan mampu melakukannya.

Peraturan Menteri Kesehatan Nomor 1419/ Menkes/Per/X/2005 tentang Penyelenggaraan Praktik Dokter dan Dokter Gigi Pasal 22 ayat (2) Dokter dan dokter gigi dalam melaksanakan praktik kedokteran harus sesuai dengan kewenangan dan kompetensi yang dimiliki serta kewenangan lainnya yang ditetapkan oleh Konsil Kedokteran Indonesia. (2) Dokter dan dokter gigi dalam keadaan gawat dan/atau darurat berwenang melakukan tindakan kedokteran atau kedokteran gigi sesuai dengan kebutuhan medis dalam rangka penyelamatan jiwa.

Artinya sebagai tenaga medis, baik dokter dan perawat memiliki kewajiban moral dalam menyelamatkan jiwa manusia, namun menjadi suatu permasalahan teknis ketika rumah sakit terikat dengan adanya BPJS, karena masingmasing peristiwa kegawatdaruratan telah terdefinisikan secara lengkap, dan memiliki konsekuensi tersendiri apabila tidak tercover yaitu harus melakukan pembayaran secara pribadi.

Pasal 25 Peraturan Presiden Republik Indonesia Nomor 19 Tahun 2016 Tentang Perubahan Kedua Atas Peraturan Presiden Nomor 12 Tahun 2013 Tentang Jaminan Kesehatan menyatakan bahwa, Pelayanan kesehatan yang tidak dijamin meliputi:

a. pelayanan kesehatan yang dilakukan tanpa melalui prosedur sebagaimana diatur dalam peraturan yang berlaku;

b. pelayanan kesehatan yang dilakukan di Fasilitas Kesehatan yang tidak bekerja sama dengan BPJS Kesehatan, kecuali dalam keadaan darurat;

c. pelayanan kesehatan yang dijamin oleh program jaminan kecelakaan kerja terhadap penyakit atau cedera akibat kecelakaan kerja atau hubungan kerja;

d. pelayanan kesehatan yang dijamin oleh program jaminan kecelakaan lalu lintas yang bersifat wajib sampai nilai yang ditanggung oleh program jaminan kecelakaan lalu lintas;

e. pelayanan kesehatan yang dilakukan di luar negeri;

f. pelayanan kesehatan untuk tujuan estetik;

g. pelayanan untuk mengatasi infertilitas;

h. pelayanan meratakan gigi (ortodonsi);

i. gangguan kesehatan/penyakit akibat ketergantungan obat dan/atau alkohol;

Ketentuan Pasal 25 ayat (1) huruf b Peraturan Presiden Republik Indonesia Nomor 19 Tahun 2016 Tentang Perubahan Kedua Atas Peraturan Presiden Nomor 12 Tahun 2013 Tentang Jaminan Kesehatan terlihat memberikan jaminan yang lengkap tanpa adanya syarat dan ketentuan tertentu. Hal ini juga dapat dilihat dalam Pasal 40 yang menyatakan bahwa: 
(1) Pelayanan gawat darurat yang dilakukan oleh Fasilitas Kesehatan yang tidak menjalin kerja sama dengan BPJS Kesehatan dibayar dengan penggantian biaya.

(2) Biaya sebagaimana dimaksud pada ayat (1) ditagihkan langsung oleh Fasilitas Kesehatan kepada BPJS Kesehatan.

(3) BPJS Kesehatan memberikan pembayaran kepada Fasilitas Kesehatan sebagaimana dimaksud pada ayat (2) setara dengan tarif yang berlaku di wilayah tersebut.

(4) Dihapus.

(5) Ketentuan lebih lanjut mengenai penilaian kegawatdaruratan dan prosedur penggantian biaya pelayanan gawat darurat diatur dengan Peraturan BPJS Kesehatan.

Pada Pasal 40 terlihat bahwa pelayanan gawat darurat yang dilakukan oleh Fasilitas Kesehatan yang tidak menjalin kerja sama dengan BPJS Kesehatan dibayar dengan penggantian biaya. Biaya tersebut juga dapat ditagihkan langsung oleh Fasilitas Kesehatan kepada BPJS Kesehatan. Hal ini juga memperlihatkan bahwa kegawatdaruratan medis akan ditanggung BPJS secara keseluruhan. Bahkan Ketentuan lebih lanjut mengenai penilaian kegawatdaruratan dan prosedur penggantian biaya pelayanan gawat darurat diatur dengan Peraturan BPJS Kesehatan. Dalam Buku Panduan Praktis Penjaminan Pelayanan Kesehatan Darurat Medis di Faskes yang Tidak Bekerjasama Dengan BPJS Kesehatan menyatakan bahwa, pada keadaan gawat darurat (emergency), seluruh fasilitas kesehatan baik yang bekerjasama maupun yang tidak bekerjasama dengan BPJS Kesehatan, wajib memberikan pelayanan kegawatdaruratan sesuai indikasi medis.

Panduan tersebut juga memberikan panduan penyakit apa saja yang ditanggung dalam kegawatdaruratan medis dalam Lampiran V antara lain terhadap anak terdapat
27 diagnosa medis dari Anemia sedang/berat hingga Tifus abdominalis dengan komplikasi, terhadap bedah terdapat 62 diagnosa dari Abses cerebri hingga Urosepsi, pada bagian Kardiovaskular terdapat 14 diagnosa dari Aritmia hingga Syncope karena penyakit jantung, pada bagian kebidanan terdapat 10 diagnosa dari Abortus hingga Persalinan kehamilan risiko tinggi dan atau persalinan dengan penyulit, pada bagian mata terdapat 12 diagnosa dari Benda asing di kornea mata/ kelopak mata hingga Uveitis/ skleritis/iritas, pada bagian paru-paru terdapat 15 diagnosa yaitu dari Asma bronchitis moderate severe hingga Tenggelam, pada bagian penyakit dalam terdapat 15 diagnosa yaitu dari Demam berdarah dengue (DBD) hingga Observasi shock, pada bagian THT terdapat 13 diagnosa yaitu Abses di bidang THT \& kepala leher hingga Vertigo (berat), dan pada bagian syaraf terdapat 3 diagnosa yaitu kejang hingga Meningo enchepalitis.

Awalnya BPJS terlihat menjamin keseluruhan kondisi kegawatdaruratan medis, namun memberikan syarat dan ketentuan yang berlaku, sehingga pada kenyataannya pasien BPJS yang mengalami kegawatdaruratan medis yang diagnosanya tidak terdaftar dalam Lampiran V buku PanduanPraktis Penjaminan Pelayanan Kesehatan Darurat Medis di Faskes yang Tidak Bekerjasama Dengan BPJS Kesehatan tidak dapat menggunkan haknya sebagai peserta BPJS dan harus membayar biaya perawatan dengan uang pribadi.

Soerjono Soekanto menyatakan bahwa masalah penegakan hukum sebenarnya terletak pada faktor-faktor yang mungkin mempengaruhinya (Soekanto, 2011: 8). Faktor faktor tersebut adalah sebagai berikut:

1. Faktor Hukum/ Undang-undang

Undang-undang merupakan peraturan tertulis yang berlaku umum dan dibuat oleh penguasa pusat maupun daerah yang sah.Undang-undang merupakan 
pengejawantahan nilai-nilai yang disepakati pemerintah.Sesuai dengan Perpres Nomor 19 tahun 2016 pasal 25 huruf b, bahwa pelayanan yang tidak dijamin adalah pelayanan yang dilakukan di fasilitas kesehatan yang tidak bekerjasama dengan BPJS Kesehatan, kecuali dalam kondisi gawat darurat. Oleh karena itu jika pasien tidak dalam kondisi gawat darurat, maka biaya pelayanan pasien tidak dapat dijamin oleh BPJS Kesehatan. Oleh karena itu bagi orangorang yang mengalami kegawatdaruratan yang tidak tertulis tidak tertanggung, hal ini tentunya menjadi masalah tersendiri.

Tidak dilayaninya pasien di luar apa yang ditanggung oleh BPJS merupakan suatu hal yang merugikan pasien, padahal setiap orang mempunyai hak yang sama dalam memperoleh akses atas sumber daya dibidang kesehatan. Setiap orang juga mempunyai hak dalam memperoleh pelayanan kesehatan yang aman, bermutu, dan terjangkau, apalagi mengingat sifat wajib dari kepesertaan BPJS.

2. Faktor penyelenggara BPJS, dan Sarana atau Fasilitas

Tanpa adanya fasilitas tertentu, maka tidak mungkin penegakan hukum akan berlangsung dengan lancar. Sarana atau fasilitas tersebut antara lain mencakup tenaga manusia yang berpendidikan dan terampil, organisasi yang baik, peralatan yang memadai, keuangan yang cukup dan lainnya. Rujukan lembaga jasa kesehatan yang ditunjuk BPJS Kesehatan terbatas dan tidak fleksibel. Peserta BPJS hanya boleh memilih satu fasilitas kesehatan untuk memperoleh rujukan dan tak bisa ke faskes lain meski sama-sama bekerja sama dengan BPJS. Keterbatasan itu, menyulitkan orang yang sering bepergian dan bekerja di tempat jauh apalagi dalam keadaan gawat darurat. Rumitnya alur pelayanan BPJS Kesehatan karena menerapkan alur pelayanan berjenjang. Sebelum ke rumah sakit, peserta wajib terlebih dulu ke faskes tingkat pertama, yaitu puskesmas.

\section{Simpulan}

1. Perlindungan hukum peserta kegawatdaruratan BPJS didasari oleh dua perlindungan yaitu perlindungan hukum peserta kegawatdaruratan BPJS berdasarkan UU SJSN, UU BPJS dan Perpres Jaminan Kesehatan serta perlindungan hukum peserta kegawataruratan BPJS berdasarkan UU Praktik Kedokteran, UU Kesehatan, dan UU Rumah Sakit. Pola perlindungan hukum berdasarkan UU SJSN, UU BPJS dan Perpres Jaminan Kesehatan dilaksanakan melalui perlindungan hak atas peserta BPJS dan hak menyampaikan keluhan terkait dengan pelayanan kesehatan dalam Jaminan Kesehatan Nasional (JKN). Berdasakan Pasal 25 huruf b Perpres Nomor 19 tahun 2016 pelayanan yang tidak dijamin adalah pelayanan yang dilakukan di fasilitas kesehatan yang tidak bekerjasama dengan BPJS Kesehatan, kecuali dalam kondisi gawat darurat, kondisi kegawatdaruratann telah ditentukan, apabila orang-orang yang mengalami kegawatdaruratan yang tidak tertulis maka tidak ditanggung oleh BPJS.

2. Pemberian informasi mengenai diagnosa gawat daruratdapat menghambat dalam pelayanan kegawatdaruratan bagi pasien pengguna BPJS di RSUD Kabupaten Sukoharjo.

\section{E. Saran}

1. Sebaiknya BPJS membuat peraturan yang memberi keleluasaan DPJP (Dokter Penanggung Jawab Pasien)untuk menetapkan diagnosa kegawatdaruratan yang masuk kriteria gawat darurat. 
2. Seharusnya BPJS profesional melakukan sosialisasi kepada masyarakat mengenai hak dan kewajiban pasien peserta BPJS, sehingga dapat mengatasi persoalanpersoalan yang timbul hubungannya dengan aturan BPJS. Khusus di IGD, BPJS menugaskan petugasnya untuk standbye di IGD memberi penjelasan kepada setiap pasien/keluarga pasien.

\section{F. Daftar Pustaka}

\section{Buku}

Ariesto Hadi Sutopo dan Adrianus. 2010. Terampil Mengolah Dara Kualitatif Dengan Metode NVIVO. Jakarta : Prenada Media Group.

Philipus M Hadjon. 1987. Perlindungan Hukum Bagi Rakyat Indonesia. Surabaya : PT. Bina Ilmu.

Hartono, Sri Redjeki. 2001.Hukum Asuransi Dan Perusahaan Asuransi. Jakarta : Sinar Grafika.

CST Kansil. 1989. Pengantar Ilmu Hukum dan Tata Hukum Indonesia. Jakarta : Balai Pustaka.

Satjipto Raharjo. 2006. Membedah Hukum Progresif. Jakarta: Penerbit Buku Kompas.

Setiono. 2004. Rule of Law (Supermasi Hukum). Surakarta : Magister Ilmu Hukum. Program Pasccasarjana Universitas Sebelas Maret.

Soerjono Soekanto. 2010. Pengantar Penelitian Hukum. Jakarta : UI-Press. . 2011. Faktor-Faktor Yang Mempengaruhi Penegakan Hukum. Jakarta : Rajawali Pers. . dan Sri Mamudji. 2007. Penelitian Hukum Normatif Suatu Tinjauan
Singkat. Jakarta : PT Raja Grafindo Persada.

Esmi Warassih. 2011. Pranata Hukum Sebuah Telaah Sosiologis. Semarang : PT. Suryandaru Utama.

\section{Jurnal, Makalah dan Data Elektronik}

Ambar Narayan dan Carolina Sanchez Paramo. 2012. "Knowing When You Do Not Know Simulationg The Poverty And Distributional Impact Of An Economics Crisis”, World Bank, June 2012.

Arief Suryono. 2003. "Tanggung Jawab Penanggung Dalam Asuransi Kesehatan di Indonesia". Disertasi pada Program Pascasarjana. Universitas Airlangga. Surabaya.

. 2008. "Asuransi Kesehatan Menurut Peraturan Pemerintah Nomor 69 Tahun 1991" HUMANIS. Jurnal Sosial Ekonomi Humaniora, Volume 2 Nomor 2, Nopember 2008. Purwokerto: Lemaga Peneliitian Universitas Jendral Sudirman

Budi Hidayat et all. 2004. The effects of mandatory health insurance on equity in access outpatient care in Indonesia. Health Policy Plan, 19 (5): 322-335

Christopher Dye et all. 2013. Research for Universal Coverage, Science Translational Medicine, Ed 13, issue 199 pp Vol. 5, 21 Agustus 2013

Edi Suharto. 2010. Peta Dan Dinamika Welfare State Di Beberapa Negara: Pelajaran apa yang bisa dipetik untuk membangun Indonesia. Jurnal Sosial UGM. http:// www. policy. hu/suharto/Naskah\% 20PDF/ UGM WelfareState. pdf.

Lapor https://www.lapor.go.id/ $\mathrm{id} / 1325735 /$ rs-puri-asih-salatiga:pasien-igd-pemegang-kartu-bpjskesehatan-tetap-membayar-iuran.html 